\title{
English Language Learning Beliefs of Jordanian Students: The Effect of Gender
}

\author{
Khaleel Bader Al Bataineh ${ }^{1}$ \\ ${ }^{1}$ Art Faculty, Irbid National University, Irbid, Jordan \\ Correspondence: Khaleel Bader Al Bataineh, Asst. Prof., English Department, Faculty of Art, Irbid National \\ University, P.O. Box 2600, Irbid 21110, Jordan. E-mail: khaleelb@inu.edu.jo
}

Received: November 3, 2018 Accepted: December 9, 2018 Online Published: February 24, 2019

doi:10.5539/ijel.v9n2p219 URL: https://doi.org/10.5539/ijel.v9n2p219

\begin{abstract}
English language learning beliefs play a key role in the language learning process, especially among EFL (English as a foreign language) learners. This study seeks to clarify English learning beliefs among EFL students in Jordan, and to examine whether female and male learners differ in these beliefs. Horwitz's (1987) Language Learning Beliefs Inventory (BALLI) was adapted to gather relevant data from 83 English major participants at a private university during regular classes. Frequency analysis and T-tests were then performed utilizing SPSS. The findings demonstrate that while Jordanian students are not sure about language difficulty, they are highly enthusiastic about learning the English language. Furthermore, female and male students only had significantly different results in two aspects of BALLI: 1) motivation and expectations and 2) difficulty of language learning. Hopefully, the results will provide constructive insights to lecturers concerning students' beliefs about learning English, which will help improve the English-learning process in Jordanian universities.
\end{abstract}

Keywords: English as a foreign language, beliefs, language learning, gender differences, Jordanian student

\section{Introduction and Aim of the Study}

In Jordan, the English learning process is considered a crucial challenge. Although Jordanian students are taught English as a foreign language (EFL) at both the school level and in institutions of higher education, they still find it difficult to master. Of course, learning a foreign language is often a difficult process, as it takes a long period of time to acquire a language besides one's mother tongue. One reason EFL students have difficulty mastering English is that they hold different beliefs about learning English. While several universities have encouraged research studies to improve EFL acquisition, little research exists on how learner beliefs influence English learning experiences in Jordan. Such work is vitally important because it can enhance teachers' awareness of how learners approach English learning. In addition, learners' beliefs influence their learning behaviors and in turn their learning outcomes. By better understanding these beliefs, universities can empower both students and teachers to improve Jordan's language education system. English language learning beliefs have a great effect on students' English learning development.

The present study was carried out to clarify English learning beliefs among EFL participants at a private university in Jordan. Based on the researcher's teaching experience at the same university, most of the students are weak in English and encounter many issues when communicating in English, even after completing enough English courses to fulfill their degree requirements. Accordingly, the study examines the participants' language learning beliefs, specifically in terms of English language motivation and expectations, communication strategies, the nature of language, and the difficulty and aptitude of learning EFL. It tries to answer two research questions:

1) What do Jordanian university students believe about EFL learning?

2) Do male and female students significantly differ in their EFL learning beliefs?

\section{Concept and Related Research}

As this study deals with students' beliefs, it is important to shed some light on the notion of belief. According to Crane (1992), "perceptions are just beliefs acquired in a certain way" (p. 150), while O'Shaughnessy (1992) notes that "perception is an experience" (p. 226). Thus, Lester (1990) asserted that beliefs are personally held perceptions about the way one learns and does things that thus guide one's daily life. While several scholars have focused on how physical actions shape one's beliefs, Horwitz (1987) affirmed that these beliefs include 
"opinions on a variety of issues and controversies related to language learning" (p. 150). The term "beliefs" here refers to learners' language learning perceptions that they can gain through certain experiences during the English learning process. These beliefs may have vital effects on their behavior and actions. To investigate the surveyed students' beliefs, the current study adapted Dr. Elaine Horwitz's (1987) Language Learning Beliefs Inventory (BALLI). Horwitz, an American scholar who pioneered studies on language learning beliefs, investigated teachers' and students' beliefs about English language motivation and expectations, communication strategies, the nature of language, and the difficulty of and aptitude for learning EFL. An understanding of all these aspects might help clarify learners' behaviors and attitudes (Benson \& Lor, 1999).

Specifically, the belief that learning English requires an exceptional capacity may affect the language learning process negatively. For example, Horwitz $(1985,1987,1988)$ and Mori (1999) asserted that students who hold such beliefs about FL learning have less achievement in language learning and may become easily discouraged. Horwitz (1989) likewise found that students who believe in FL aptitude more anxious, as are those who believe that the target language is relatively difficult (Horwitz, 1989; Truitt, 1995). Beliefs about the difficulty or ease of English language are associated with language achievement and were found to relate to successful language learning. Thus, students who hold positive beliefs, i.e., that the target language is easy, learn faster than those with negative beliefs that it is a difficult language (Mori, 1999). In contrast, Horwitz $(1985,1987)$ affirmed that wrongly estimating the FL's difficulty may have negative effects on FL learners, as their thoughts about language difficulty influence their expectations about language learning and may discourage them from continuing in their learning. Similarly, Peacock (1999) noted that students who had a more realistic estimate tended to have higher achievement than those who underestimated the difficulty of language learning.

Additionally, the nature of FL learning includes many aspects involving cultural contact, learning immersion, learning vocabulary words, learning grammar, translation from the native language, and how FL learning differs from learning other academic topics. According to Horwitz (1989), these issues retain a great influence on the language learning process. Atlan (2006) investigated beliefs about FL learning among 248 undergraduate students at five different Turkish universities. He affirmed that respondents believe that learning novel vocabulary words or grammar rules are among the main reasons for learning achievement. On the contrary, they rejected that "learning a FL is mostly a matter of translating from the target language". In his study, Daif-Allah (2012) also reported that most respondents agreed that FL learning is different from learning other academic topics and thought that being familiar with the culture of the target language's native speakers is essential. More than half of his respondents also affirmed that Arabic and English are structurally dissimilar.

Beliefs about communication strategies were also found to be related to successful language learning process, as these beliefs are directly associated with actual students' language learning performance, learning strategies, and communication strategies. In spite of this, beliefs related to correct pronunciation and self-confidence in speaking an FL were discussed in terms of their negative effect on learning process. Daif-Allah (2012) found that students in his study believed that communication and learning strategies would affect their efforts to secure achievements in EFL learning. Suwanarak (2012) demonstrated that a great number of the respondents believed in regular language exercise to improve one's language learning and communication skills. Al-Roomy (2015) asserted that students thought that utilizing modern technology greatly facilitated the learning process, although the majority of them lacked experience of language lab technology in English learning. They also thought that making mistakes was not a problem while speaking English in person, as these mistakes could be amended later. Similarly, most of the students agreed that "It is OK to guess if you do not know a word in the FL" and they reported that they were ready to practice what they learned in front of native speakers. Moreover, beliefs related to motivation and expectations were connected to the importance of FL speaking, which enables students to be acquainted with international colleagues and have good career opportunities. Jusoh (2017), Al-Roomy (2015), Alsmaani (2012), and Daif-Allah (2012) found that the majority of their participants were eager to learn English to know more about people of the target language and to have a good chance to gain better jobs.

Because the study of language learning beliefs is still a point of contention for many researchers, many studies have investigated what students believe about learning FLs in general and how gender affects their beliefs (Al-Mekhlafi, 2017; Al-Roomy, 2015; Alsmaani, 2012; Ariogul, 2009; Daif-Allah, 2012; Javid \& Al Malki, 2017; Horwitz, 1987; Jusoh, 2017; Oz, 2007; Peacock, 2001; Tahaineh, 2013; Tercanlioglu, 2004; Zhou, 2018).

This study was conducted to clarify English learning beliefs among EFL participants in Jordan. In the Jordanian context, EFL students' beliefs about language learning have not yet been fully elucidated. Only one study has examined their overall language learning beliefs. Asassfeh (2013) utilized BALLI on a sample of two hundred female and male university students. The findings revealed that beliefs about the difficulty of language learning were the least common, whilst those related to motivation were the most common. Moreover, language learning 
beliefs varied according to the study variables. Motivation to learn English, language learning difficulties, and communication strategies were investigated disjointedly by a number of studies such as $\mathrm{Al}$ Garaibeh and Al-Jamal (2016), Asassfeh et al. (2011), and Tahaineh and Daana (2013).

\section{Method and Procedures}

\subsection{Research Design}

This descriptive study employs a survey instrument to investigate EFL students' beliefs about language learning and its relation to gender. Survey research emphasizes respondents' important characteristics, as well as their behaviors, motivations, attitudes, and beliefs (Kerlinger, 1973).

\subsection{Subjects}

The subjects were male and female students enrolled in the department of English language and literature at a private university during the second semester of the 2017/2018 academic year. 83 students participated (35 males and 48 females), and their ages were between 18 to 45 years old.

\subsection{The Study Instrument}

A set of questionnaires were used from Horwitz's (1987) Language Learning Beliefs Inventory (BALLI) and deployed to gather the data. The BALLI includes 34 items pertaining to five aspects of student beliefs: English language motivation and expectations, communication strategies, the nature of language, and difficulty of and aptitude for learning EFL. The instrument features Likert answer choices (a scale from 1-5) which used a forced choice format, in which subjects were expected to select from one of the five choices. The participants were also asked to respond to questions concerning demographic information such as age and sex. The questionnaires were distributed to all of the department students (100 students) and 83 completed questionnaires were returned. The participants represented $83 \%$ of the population. The sample is acceptable as it represented more than $80 \%$ of population (Krejcie \& Morgan, 1970).

A pilot test study was conducted to check the used questionnaire with regard to the strength and consistency of its internal reliability. The questionnaire was completely valid and reliable without a doubt, as the results of the reliability coefficient for the pilot study (Cronbach's alpha) was measured at 0.88 .

\subsection{Data Analysis}

After collecting the desired data, the students' responses were analyzed utilizing the Statistical Package for the Social Sciences (SPSS) program with which a T-test and frequency tests were carried out. SPSS statistical inferential techniques were utilized to test the difference in the subjects' beliefs about EFL learning according to gender. In addition, an independent T-test was performed at a 0.05 level of significance to examine differences between the male and female respondents. A p value of less than alpha (0.05) was considered as a significant difference between the groups.

\section{Results and Discussion}

This study seeks to explore the English learning beliefs of Jordanian EFL students, and to examine the gender-based differences among these beliefs. The results are presented below and discussed in terms of the research questions.

To answer the first question, "What do Jordanian university students believe about EFL learning?", answer frequencies were calculated with respect to the five measured aspects: English language motivation and expectations, communication strategies, nature of language, difficulty of learning EFL, and aptitude for learning EFL. The students responded to nine items regarding English language aptitude. These items deal with the concept of individual capacity for language learning and with readiness and quickness in language learning. 
Table 1. Aptitude beliefs

\begin{tabular}{|c|c|c|c|c|c|c|}
\hline & & Strongly Agree & Agree & Neutral & Disagree & Strongly Disagree \\
\hline 1 & It is easier for kids to learn English than adults. & $56.6 \%$ & $33.7 \%$ & $8.4 \%$ & $1.2 \%$ & $00.0 \%$ \\
\hline 2 & Some individuals have a unique capability for learning English. & $22.9 \%$ & $65.1 \%$ & $9.6 \%$ & $2.4 \%$ & $00.0 \%$ \\
\hline 3 & Jordanian people are capable at learning English. & $7.2 \%$ & $48.2 \%$ & $33.7 \%$ & $8.4 \%$ & $2.4 \%$ \\
\hline 4 & $\begin{array}{l}\text { It is easier for someone who already speaks English to learn } \\
\text { another language. }\end{array}$ & $15.7 \%$ & $45.8 \%$ & $18.1 .0 \%$ & $20.5 \%$ & $00.0 \%$ \\
\hline 5 & $\begin{array}{l}\text { People who are good at mathematics or science are not good at } \\
\text { English. }\end{array}$ & $4.8 \%$ & $25.3 \%$ & $20.5 \%$ & $34.9 \%$ & $14.5 \%$ \\
\hline 6 & I have a special ability for English learning. & $16.9 \%$ & $51.8 \%$ & $31.3 \%$ & $00.0 \%$ & $00.0 \%$ \\
\hline 7 & Females are better than males at English learning. & $6.0 \%$ & $48.2 \%$ & $10.8 \%$ & $26.5 \%$ & $8.4 \%$ \\
\hline 8 & $\begin{array}{l}\text { People who speak more than one language perfectly are very } \\
\text { intelligent. }\end{array}$ & $43.4 \%$ & $36.6 \%$ & $16.9 \%$ & $00.0 \%$ & $1.2 \%$ \\
\hline 9 & Everyone can learn to speak English. & $30.1 \%$ & $56.6 \%$ & $9.6 \%$ & $00.0 \%$ & $3.6 \%$ \\
\hline
\end{tabular}

The previous table shows that $90.3 \%$ (the highest percentage) of the students believed that "it is easier for kids to learn English than adults" while only $1.2 \%$ of the students rejected this statement. The great majority of these students accept that age is a very vital factor in FL learning. This result concurs with the common knowledge that children's brains can soak up a FL remarkably well. However, only $2.4 \%$ of the students strongly disagreed that "some individuals have a unique capability for learning English." The majority of these students felt that the ability to learn English language varies among individuals. 55.4\% of the students agreed that "Jordanian people are capable at learning English" whilst $10.8 \%$ of the students rejected the statement. It seems that the students feel that Jordanians do have a special competence in learning English for many reasons, such as Jordan's strong connections and ties with western countries. In addition, $61.5 \%$ of the students accepted the following statement: "It is easier for someone who already speaks English to learn another language." $20.5 \%$ of the students rejected this statement. Learning a third language is much easier than learning the second one.

Interestingly, $30.1 \%$ of the students believed that "people who are good at mathematics or science are not good at learning English." Overall, the students believe that learning English requires a special ability and that there is no relationship between learning English and other subject ability. $68.7 \%$ of them agreed that "I have a special ability for English learning." The majority of the students were optimistic about their abilities and distinguished themselves as having an exceptional capacity to learn English. 34.9\% of the students rejected the notion that "females are better than males at learning English," while $54.2 \%$ of them felt that women have a unique competency in language learning. However, $80 \%$ of the students were in agreement that "People who speak more than one language perfectly are very intelligent." According to the students, one's intelligence affects language learning. Finally, $86.7 \%$ of them endorsed the idea that everyone is able to learn to speak English. Generally, the students tended to hold positive beliefs on the existence of English language aptitude and thought that they had significant EFL aptitude. This result is in line with many previous studies (Al-Mekhlafi, 2017; Al-Roomy, 2015; Daif-Allah, 2012; Javid \& Al Malki, 2017). For instance, Daif-Allah (2012) pinpointed that English major students held positive beliefs about their abilities to learn English.

Six items addressed students' beliefs about the difficulty of language learning, including the relative difficulty of learning English and the duration required for language mastery.

Table 2. Difficulty beliefs

\begin{tabular}{lllllll}
\hline & & Strongly Agree & Agree & Neutral & Disagree & Strongly Disagree \\
\hline 10 & Some languages are easier to learn than others. & $66.3 \%$ & $19.3 \%$ & $9.6 \%$ & $1.2 \%$ & $3.6 \%$ \\
11 & English is an easy language. & $13.3 \%$ & $39.8 \%$ & $39.8 \%$ & $4.8 \%$ & $2.4 \%$ \\
12 & I believe that I will learn to speak English very well. & $61.4 \%$ & $33.7 \%$ & $3.6 \%$ & $1.2 \%$ & $00.0 \%$ \\
13 & A student can learn to speak English perfectly in less than & $38.6 \%$ & $36.1 \%$ & $36.3 \%$ & $22.9 \%$ & $2.4 \%$ \\
& $\begin{array}{l}\text { a year if he or she spends one hour a day learning English. } \\
14\end{array}$ & & & & \\
15 & It is easier to speak English than to understand it. & $12.0 \%$ & $28.9 \%$ & $14.5 \%$ & $31.3 .8 \%$ & $13.3 \%$ \\
& It is easier to read and write English than to speak and & $18.1 \%$ & $9.6 \%$ & $14.5 \%$ & $45.8 \%$ & $12.0 \%$ \\
& & & & & \\
\hline
\end{tabular}

As shown in Table 2, 66.3\% of the students strongly agreed and $19.3 \%$ agreed with the first item, "some languages are easier to learn than others," while $3.6 \%$ of them rejected the statement. They likely affirmed that 
some languages are more challenging since English and Arabic are not from the same linguistic family. Slightly over half $(53.1 \%)$ of the students agreed that the English language is easy. The students are evidently not sure about the language's difficulty. Most (95.1\%) of the students believed that they would learn to speak English correctly, showing that they are enthusiastic and self-confident about learning English. $40.4 \%$ of the students believe that speaking English is easier than understanding it, while $57.8 \%$ of the students disagreed that reading and writing English is easier than speaking and understanding it. Thus, the students asserted that speaking skills are easier than reading and writing skills. Finally, $74.7 \%$ of the students believed that an hour a day of English practice would lead to perfect mastery in less than a year. These students are eager to learn English since they are alert to the importance of the English language in Jordan; for instance, mastering the English language is one of the major requirements of any postgraduate program in the country.

The present finding concurs with Daif-Allah (2012), whose participants agreed that some languages are easier than others and that they were confident that they would learn English very well. However, these results conflict with other findings (e.g., Al-Roomy, 2015; Hismanoglu, 2016; Jusoh, 2017). For instance, Jusoh (2017) conducted a study of mostly female students who were learning different languages. His finding shows that most Malaysian students (76\%) believed that language is difficult to learn while $79 \%$ of the students set impracticable period to master English. A small percentage (21\%) of the students believed that speaking was easier than understanding English and they were unsure about the importance of speaking, as $45 \%$ of them were neutral as to whether speaking English is easier than understanding it.

Table 3 illustrates the six items addressing students' beliefs about the nature of language.

Table 3. Nature of language beliefs

\begin{tabular}{|c|c|c|c|c|c|c|}
\hline & & Strongly Agree & Agree & Neutral & Disagree & Strongly Disagree \\
\hline 16 & $\begin{array}{l}\text { It is necessary to know about English-speaking cultures in } \\
\text { order to speak English. }\end{array}$ & $20.5 \%$ & $59.0 \%$ & $19.3 \%$ & $1.2 \%$ & $00.0 \%$ \\
\hline 17 & It is best to learn English in an English-speaking country. & $61.4 \%$ & $27.7 \%$ & $8.4 \%$ & $2.4 \%$ & $00.0 \%$ \\
\hline 18 & $\begin{array}{l}\text { The most important part of learning English is learning } \\
\text { vocabulary words. }\end{array}$ & $21.7 \%$ & $36.1 \%$ & $37.3 \%$ & $4.8 \%$ & $00.0 \%$ \\
\hline 19 & $\begin{array}{l}\text { The most important part of learning English is learning } \\
\text { the grammar. }\end{array}$ & $8.4 \%$ & $38.6 \%$ & $8.4 \%$ & $44.6 \%$ & $00.0 \%$ \\
\hline 20 & $\begin{array}{l}\text { Learning English is different than learning other academic } \\
\text { subjects. }\end{array}$ & $6.0 \%$ & $44.6 \%$ & $16.9 \%$ & $32.5 \%$ & $00.0 \%$ \\
\hline 21 & $\begin{array}{l}\text { The most important part of learning English is learning } \\
\text { how to translate from my native language. }\end{array}$ & $21.7 \%$ & $42.2 \%$ & $14.5 \%$ & $21.7 \%$ & $00.0 \%$ \\
\hline
\end{tabular}

Table 3 illustrates that most students (79.5\%) agreed that "it is necessary to know about English-speaking cultures in order to speak English" while 1.2\% rejected this statement. Similarly, $89.1 \%$ of them accepted that "it is best to learn English in an English-speaking country" whilst 2.4\% of the students rejected this notion. Students are aware that language immersion and cultural contact assist positively in language success. Slightly over half of the students felt that learning grammar and vocabulary are vital parts of learning English language. Data revealed that $57.8 \%$ (21.7\% strongly agreed and $36.1 \%$ agreed) of the students believed that "the most important part of learning English language is learning vocabulary words," while 47\% (8.4\% strongly agreed and 38.6\% agreed) felt that learning grammar is the most vital element of learning English language.

In response to "the most important part of learning English is learning how to translate from my native language", $63.9 \%$ of the students agreed while $21.7 \%$ disagreed. These students indicate strong agreement with the consequence of translation learning. They seemed to be affected by their schools' teaching approaches, which typically follow the grammar translation approach that focuses on vocabulary lists, grammar, and translation texts. $50.6 \%$ of them agreed that "learning English is different than learning other academic subjects" while 32.5\% rejected this statement. This indicates a good consensus concerning the nature of EFL learning compared to other academic topics. It seems that the students hold positive beliefs concerning how to master English language. This finding is consistent with many studies such as those by Jusoh (2017) and Hismanoglu (2016), who pinpointed that the students show positive beliefs on most items regarding the nature of language learning.

Eight items focused on communication strategies and their effects on learning. These items are illustrated in Table 4. 
Table 4. Learning and communication strategies beliefs

\begin{tabular}{|c|c|c|c|c|c|c|}
\hline & & Strongly Agree & Agree & Neutral & Disagree & Strongly Disagree \\
\hline 22 & It is important to speak English with excellent pronunciation. & $38.6 \%$ & $18.1 \%$ & $6.0 \%$ & $34.9 \%$ & $2.4 \%$ \\
\hline 23 & $\begin{array}{l}\text { You shouldn't say anything in English until you can say it } \\
\text { correctly. }\end{array}$ & $8.4 \%$ & $6.0 \%$ & $13.3 \%$ & $38.6 \%$ & $33.7 \%$ \\
\hline 24 & $\begin{array}{l}\text { I enjoy practicing English with people from the } \\
\text { English-speaking countries I meet. }\end{array}$ & $26.5 \%$ & $55.4 \%$ & $15.7 \%$ & $1.2 \%$ & $1.2 \%$ \\
\hline 25 & It's O.K. to guess if you don't know a word in English. & $30.1 \%$ & $44.6 \%$ & $19.3 \%$ & $4.8 \%$ & $1.2 \%$ \\
\hline 26 & It is important to repeat and practice a lot. & $60.2 \%$ & $26.5 \%$ & $10.8 \%$ & $1.2 \%$ & $1.2 \%$ \\
\hline 27 & I feel timid speaking English with other people. & $8.4 \%$ & $67.5 \%$ & $14.5 \%$ & $8.4 \%$ & $1.2 \%$ \\
\hline 28 & $\begin{array}{l}\text { If beginning students are permitted to make errors in English, } \\
\text { it will be difficult for them to speak correctly later on. }\end{array}$ & $10.8 \%$ & $50.6 \%$ & $13.3 \%$ & $14.5 \%$ & $10.8 \%$ \\
\hline 29 & It is important to practice with audio-visual materials. & $50.6 \%$ & $30.1 \%$ & $18.1 \%$ & $00.0 \%$ & $1.2 \%$ \\
\hline
\end{tabular}

Data revealed that $37.3 \%$ of the students disagreed that "it is important to speak English with excellent pronunciation," while $56.7 \%$ of them agreed. They perceived the great value of accurate pronunciation along with vocabulary words and grammatical roles. On the other hand, only $14.4 \%$ of them believed that they "shouldn't say anything in English until [they] can say it correctly." These results come from the current teaching approaches that don't stress fluency. Most (81.9\%) of the study respondents agreed that "they enjoy practicing English with people from the English-speaking countries they meet" while 15.7\% selected a neutral response and $2.4 \%$ disagreed with the statement. There is a consensus among the students about enjoying talking to native speakers. Also, data revealed that $74.7 \%$ of respondents supported the statement that "it's O.K. to guess if you don't know a word in English," while 6\% of them rejected it. This finding is consistent with the common belief that guessing is among the essential abilities in learning a language.

Furthermore, most $(86.7 \%)$ of the students endorsed the importance of repeating and practicing. Students indicated strong agreement with the significance of guessing when learning a language, along with the significance of repeating and practicing. However, the majority (61.4\%) of them felt shy speaking English with other people, because they could be mistaken when they speak. Shyness is a major issue encountered among the students. Students also felt fear and anxiety talking in English as they failed to make use of affective strategies such as "encouraging themselves to speak" and "trying to relax." This result agrees with Horwitz et al. (1986), who asserted that feelings of anxiety or tension center on listening and speaking as task requirements of FL learning. $61.4 \%$ of the students accepted the notion that "if beginning students are permitted to make errors in English, it will be difficult for them to speak correctly later on." This belief shows that students seemed to hold a high regard for accuracy and rising awareness. Finally, $80.7 \%$ of the students felt that practicing with audio-visual materials is important. However, this finding is not surprising as audio-visual materials are integrated in their learning language process and the students are mindful about the benefits of utilizing them. These results bear strong agreement with Daif-Allah (2012), as he found that the subjects of his study maintained unrealistic beliefs concerning error correction and accuracy that may influence the language learning process.

The last aspect of the BALLI focuses on motivation and expectations. It relates to the desire and belief for language learning opportunities. This aspect is covered by five items, presented in Table 5 .

Table 5. Motivation and expectations beliefs

\begin{tabular}{|c|c|c|c|c|c|c|}
\hline & & Strongly Agree & Agree & Neutral & Disagree & Strongly Disagree \\
\hline 30 & People in Jordan feel that it is important to speak English. & $30.1 \%$ & $54.2 \%$ & $3.6 \%$ & $3.6 \%$ & $8.4 \%$ \\
\hline 31 & $\begin{array}{l}\text { I would like to learn English so that I can get to know } \\
\text { people from English-speaking countries better. }\end{array}$ & $33.7 \%$ & $50.6 \%$ & $10.8 \%$ & $3.6 \%$ & $1.2 \%$ \\
\hline 32 & $\begin{array}{l}\text { If I learn English very well, I will have better opportunities } \\
\text { for a good job. }\end{array}$ & $72.3 \%$ & $16.9 \%$ & $00.0 \%$ & $9.6 \%$ & $1.2 \%$ \\
\hline 33 & I want to learn to speak English well. & $79.5 \%$ & $14.5 \%$ & $00.0 \%$ & $4.8 \%$ & $1.2 \%$ \\
\hline 34 & $\begin{array}{l}\text { I would like to have friends from English-speaking } \\
\text { countries. }\end{array}$ & $39.8 \%$ & $49.4 \%$ & $00.0 \%$ & $8.4 \%$ & $2.4 \%$ \\
\hline
\end{tabular}

Regarding beliefs about motivation and expectations, the majority $(84.3 \%)$ of the respondents reported that Jordanians think speaking English is vitally important, while only $12 \%$ rejected this statement. They have strong encouraging beliefs that reflect their awareness of the importance of English proficiency in Jordan. Thus, 84.3\% 
indicated that "they would like to learn English so that they can get to know people from the English-speaking countries better." Besides knowing English-speaking people, students were sure that English language learning would offer them better chances for a good job post, as only $10.8 \%$ of the students disagreed with this notion while $89.2 \%$ of the students supported it. Moreover, $94 \%$ of the students wanted to learn to speak English correctly: speaking proficiency was given a great value. The students held a strong desire to be taught to speak English correctly as $89.2 \%$ of them were eager to have friends from English-speaking countries. To sum up, Jordanian students are highly excited to study the English language and they are sure that English is important in Jordan. These findings coincide with many studies such as that by Asassfeh (2013) who noted that the subjects of his study had optimistic beliefs about motivation and expectations.

To answer the second research question about whether male and female respondents differed significantly in their EFL teaching beliefs, an independent T-test was performed to test the difference in the subjects' beliefs in terms of gender. The following tables demonstrate those differences.

Table 6. Males' and females' beliefs

\begin{tabular}{llllllll}
\hline & Group & $\mathrm{N}$ & $\mathrm{M}$ & $\mathrm{S}$. D. & $\mathrm{T}$ & Df & Sig. (2-tailed) \\
\hline English Language Aptitude & Male & 35 & 3.73 & .351 & -.140 & 81 & .889 \\
& Female & 48 & 3.75 & .413 & & & \\
Difficulty of Language Learning & Male & 35 & 3.33 & .531 & 2.541 & 81 & .013 \\
& Female & 48 & 3.06 & .446 & & & \\
Nature of Language Learning & Male & 35 & 3.73 & .366 & .447 & 81 & .656 \\
& Female & 48 & 3.68 & .553 & & & \\
Learning and Communication Strategies & Male & 35 & 3.70 & .225 & .018 & 81 & .985 \\
& Female & 48 & 3.70 & .303 & & & \multirow{2}{*}{.031} \\
Motivation and Expectations & Male & 35 & 4.19 & .542 & -2.196 & 81 & \\
& Female & 48 & 4.43 & .438 & & & \\
\hline
\end{tabular}

From the two-tailed independent samples t-test, females and males are not significantly different with respect to three aspects of students' beliefs: English language communication strategies, the nature of language learning, and language aptitude. Conversely, females and males significantly differ on the difficulty of language learning. The mean of females $(n=48, m=3.06$, st.d. $=0.446)$ was lower than that of male students $(n=35, m=3.33$, st.d. $=0.531$ ). This result is inconsistent with Zhou (2018), who found that female and male students are not significantly different in learning difficulties. Also, in terms of motivation and expectations, female students had higher means $(\mathrm{n}=48, \mathrm{~m}=4.43$, st.d. $=0.438)$ than male students $(\mathrm{n}=35, \mathrm{~m}=4.19$, st.d. $=0.542)$. This finding agrees with Zhou's finding that there is a gender effect on students' beliefs about motivation and expectations. The following tables illustrate these differences in detail.

Table 7. Language difficulty beliefs in terms of gender

\begin{tabular}{|c|c|c|c|c|c|c|c|}
\hline & Group & $\mathrm{N}$ & $\mathrm{M}$ & S. D. & $\mathrm{T}$ & Df & Sig. (2-tailed) \\
\hline \multirow[t]{2}{*}{ Some languages are easier to learn than others. } & Male & 35 & 4.29 & 1.126 & $-1.181-$ & 81 & .241 \\
\hline & Female & 48 & 4.54 & .849 & & & \\
\hline \multirow[t]{2}{*}{ English is an easy language. } & Male & 35 & 3.60 & .775 & .299 & 81 & .766 \\
\hline & Female & 48 & 3.54 & .944 & & & \\
\hline \multirow[t]{2}{*}{ I believe that I will learn to speak English very well. } & Male & 35 & 4.51 & .742 & $-.491-$ & 81 & .625 \\
\hline & Female & 48 & 4.58 & .539 & & & \\
\hline \multirow{4}{*}{$\begin{array}{l}\text { A student can learn to speak English perfectly in less than } \\
\text { a year if he or she spends one hour a day learning English. } \\
\text { It is easier to speak English than understand it. }\end{array}$} & Male & 35 & 3.49 & 1.422 & $-2.403-$ & 81 & .019 \\
\hline & Female & 48 & 4.13 & 1.003 & & & \\
\hline & Male & 35 & 3.29 & 1.100 & 2.074 & 81 & .041 \\
\hline & Female & 48 & 2.71 & 1.352 & & & \\
\hline \multirow{2}{*}{$\begin{array}{l}\text { It is easier to read and write English than to speak and } \\
\text { understand it. }\end{array}$} & Male & 35 & 3.37 & 1.265 & 3.939 & 81 & .000 \\
\hline & Female & 48 & 2.31 & 1.170 & & & \\
\hline
\end{tabular}

With regard to the above table, females were more likely than their male colleagues to believe that students require a short period of time to attain fluency in English. The effect of gender is also obvious in the items pertaining to English skills. More male than female students asserted that speaking English is easier than understanding it. Also, more male than female students appeared to consider writing and reading English easier 
than understanding and speaking it. It seems that male students have better awareness of reading and writing skills. This finding comes from the teaching approaches used by their professors that don't stress speaking, and concurs with researchers such as Daif-Allah (2012), who argued that male students found reading and writing easier than speaking and understanding English and also required a longer time to master language and achieve fluency. Conversely, in another study carried out by Hismanoglu (2016), female and male students showed disagreement with respect to writing and reading skills being easier than understanding and speaking English.

Table 8. Motivation and expectations beliefs in terms of gender

\begin{tabular}{llllllll}
\hline & Group & $\mathrm{N}$ & $\mathrm{M}$ & $\mathrm{S}$. D. & $\mathrm{T}$ & Df & Sig. (2-tailed) \\
\hline People in Jordan feel that it is important to speak & Male & 35 & 3.63 & 1.477 & $-2.214-$ & 81 & .030 \\
English. & Female & 48 & 4.17 & .694 & & & \\
I would like to learn English so that I can get to know & Male & 35 & 4.06 & .968 & $-.590-$ & 81 & .557 \\
people from English-speaking countries better. & Female & 48 & 4.17 & .724 & & & \\
If I learn English very well, I will have better & Male & 35 & 4.40 & .812 & $-2.258-$ & 81 & .027 \\
opportunities for a good job. & Female & 48 & 4.75 & .601 & & & \\
I want to learn to speak English well. & Male & 35 & 4.63 & 0.690 & $-1.204-$ & 81 & .232 \\
I would like to have friends from English-speaking & Female & 48 & 4.79 & 0.544 & & & \\
countries. & Male & 35 & 4.23 & 1.060 & $-.119-$ & 81 & .906 \\
\hline
\end{tabular}

The results of the t-test showed that females and males significantly differ in two items out of five. Both genders had significant concerns in respect to the importance of speaking English language $(p=.030)$ and the importance of English language learning to improve one's chances for a good career $(p=.027)$. However, female students showed stronger agreement with the importance of the English language in Jordan and its role in having a good career, as they were keener for English language learning than the male students. This result agrees with many researchers such as Zhou (2018), Diab (2006), and Siebert (2003), who asserted that female students were more enthusiastic and confident to learn an FL than male students. Conversely, the above findings strongly contrast with results by Mesri (2012) and Tercanlioglu (2005), who found that females and males were not significantly different with regard to these beliefs.

\section{Limitations}

This current study is limited to students of English language at a private university. More studies of other students from different universities are necessary to generalize from the results. This descriptive study also used only one questionnaire (BALLI), so using different methodologies such as interviews and observations would permit triangulation of the data to accomplish truthful and dependable results.

\section{Conclusion and Implications}

This study aimed at answering two research questions. The data from the first question about language learning beliefs demonstrates that students in the current study hold the highest mean rank in beliefs on motivation and expectation (4.33) and the lowest mean rank in beliefs on the difficulty of language learning (3.17). They tended to hold positive beliefs about English language aptitude, so accordingly they believed that they had high English language aptitude. Even though the students were not sure about language difficulty, it seems they are highly motivated and self-confident in learning the English language, as they are alert to the importance of the English language in Jordan. It was also found that the respondents of the study hold positive beliefs concerning how to master the English language. They indicate strong agreement with the importance of guessing in language, repeating and practicing, and using audio-visual materials.

Regarding the second research question related to gender, it was found that female and male students are significantly different in only two aspects of BALLI: motivation and expectations, and the difficulty of language learning. Conversely, females and males were not significantly different with respect to English language communication strategies, the nature of language learning, and language aptitude. Females were more likely than their male colleagues to support that students require a short period of time to attain fluency in English. However, more male than female students asserted that speaking English is easier than understanding it. It seems that male students have better awareness of productive skills. Even though both genders showed encouraging beliefs about learning English language concerning motivation and expectations, female students more strongly agreed with the importance of English in Jordan and its role in having a good career, as they were more enthusiastic to study English language than the male students. 
Overall, the results of the present study provide informative insights into students' beliefs about language learning. Educators should take these beliefs into consideration in designing instructional materials that meet the students' needs. The results can also assist teachers of English to develop better language learning and teaching processes.

\section{References}

Al Garaibeh, S., \& Al-Jamal, D. (2016). Communication strategies for teachers and their students in an EFL setting. International Journal of Bilingual \& Multilingual Teachers of English, 4(1) 33-44. https://doi.org/10.12785/ijbmte/040105

Al Mekhlafi, M. A. (2017). The beliefs of Yameni EFL student teachers about their English language learning. Journal for Research Scholars and Professionals of English Language Teaching, 1(3), 1-18. Retrieved from http://www.jrspelt.com/wp-content/uploads/2017/07/Al-Mekhlafi-The-Beliefs-of-Yemeni-EFL-Student-Tea chers.pdf

Al-Roomy, M. (2015). Evaluating Saudi University Students' Beliefs about Learning English. International Journal of English Linguistics, 5(1), 22-31. https://doi.org/10.5539/ijel.v5n1p22

Alsamaani, A. (2012). Assessing Saudi learners' beliefs about English language learning. International Journal of English and Education, 1(2), 31-55. Retrieved from http://ijee.org/yahoo_site_admin/assets/docs/Dr_Abdulaziz_al.273105809.pdf

Ariogul, S., Unal, D. C., \& Onursal, I. (2009). Foreign language learners' beliefs about language learning: a study on Turkish university students. Procedia Social and Behavioral Sciences, 1(1), 1500-1506. https://doi.org/10.1016/j.sbspro.2009.01.265

Asassfeh S. M. (2013) Prospective EFL teachers: what language learning beliefs do they hold? The Asia-Pacific Education Researcher, 24(1), 13-26. https:// doi.org/10.1007/s40299-013-0154-1

Asassfeh, S., Zuraiq, W., Al-Shaboul, Y., \& Shbool, S. (2011). Lending ears to EFL learners: Language difficulties. The Australian Educational and Developmental Psychologist, 28(1), 33-46. https://doi.org/10.1375/aedp.28.1.33

Atlan, M. X. (2006). Beliefs about language learning of foreign language- major university students. Australian Journal of Teacher Education, 31(2), 45-52. https:// doi.org/10.14221/ajte.2006v31n2.5

Benson, P., \& Lor, W. (1999). Conceptions of language and language learning. System, 27(4), 459-472. https://doi.org/10.1016/S0346-251X(99)00045-7

Crane, T. (1992). The non-conceptual content of experience. In T. Crane (Ed.), The contents of experience: Essays on perceptions (pp. 136-157). Cambridge, UK: Cambridge University Press. https://doi.org/10.1017/CBO9780511554582

Daif-Allah, A. S. (2012). Beliefs about foreign language learning and their relationship to gender. English Language Teaching, 5(10), 20-33. https://doi.org/10.5539/elt.v5n10p20

Diab, R. L. (2006). University students' beliefs about learning English and French in Lebanon. System, 34(1), 80-96. https://doi.org/10.1016/j.system.2005.06.014

Javid, C. Z., \& Al-malki, E. A. (2018). Saudi university undergraduates' beliefs about language learning along gender lines. International Journal of English Linguistics, 4(8), 39-49. https://doi.org/10.5539/ijel.v8n4p39

Jusoh, Z. (2017). Evaluating TESL Students' Beliefs about Foreign Language Learning. International Journal of English Linguistics, 6(7), 228-235. https://doi.org/10.5539/ijel.v7n6p228

Hismanoglu, M. (2016). A study on English preparatory program EFL learners' beliefs about language learning in relation to gender, second foreign language knowledge and foreign country experience. International Journal of Applied Linguistics \& English Literature, 5(5), 109-118. Retrieved from http://www.journals.aiac.org.au/index.php/IJALEL/article/view/2496

Horwitz, E. K. (1985). Surveying student beliefs about language learning and teaching in the foreign language methods course. Foreign Language Annals, 18(4), 333-340. https://doi.org/10.1111/j.1944-9720.1985.tb01811.x

Horwitz, E. K., Horwitz, M. B., \& Cope, J. (1986). Foreign language classroom anxiety. The Modern Language Journal, 70, 125-132. https://doi.org/10.1111/j.1540-4781.1986.tb05256.x

Horwitz, E. K. (1987). Surveying student beliefs about language learning. In A. Wenden, \& J. Rubin (Eds.), 
Learner strategies in language learning (pp. 119-129). Englewood Cliffs, NJ: Prentice-Hall.

Horwitz, E. K. (1988). The beliefs about language learning of beginning foreign language students. Modern Language Journal, 72(3), 283-294. https://doi.org/10.1111/j.1540-4781.1988.tb04190.x

Horwitz, E. K. (1989). Facing the blackboard: Student perceptions of language learning and the language classroom. ADFL Bulletin, 20(3), 61-64. https://doi.org/10.1632/adfl.20.3.61

Kerlinger, F. N. (1973) Foundations of behavioral research (2nd ed.). Holt: Rinehart and Winston.

Krejcie, R. V., \& Morgan, D. W. (1970). Detemining sample size for research activities. Educational and Psychological Measurement, 30, 607-610. https://doi.org/10.1177/001316447003000308

Lester, F. (1990). Influence of teachers'beliefs. New York: New bury House.

Mesri, F. (2012). The relationship between gender and Iranian EFL learners' foreign language classroom anxiety (FLCA). International Journal of Academic Research in Business and Social Sciences, 2(6), 147-156 Retrieved from http://hrmars.com/admin/pics/841.pdf

Mori, Y. (1999). Epistemological beliefs and language learning beliefs: What do language learners believe about their learning? Language Learning, 49(3), 377-415. https://doi.org/10.1111/0023-8333.00094

O'Shaughnessy, B. (1992). The diversity and unity of action and perception. In T. Crane (Ed.), The contents of experience: Essays on perceptions (pp. 216-266). Cambridge, UK: Cambridge University Press. https://doi.org/10.1017/CBO9780511554582.011

Oz, H. (2007). Understanding metacognitive knowledge of Turkish EFL students in secondary education. Novitas-Royal, 1(2), 53-83. Retrieved from http://www.novitasroyal.org/Oz.pdf

Peacock, M. (1999). Beliefs about language learning and their relationship to proficiency. International Journal of Applied Linguistics, 9(2), 247-265. https://doi.org/10.1111/j.1473-4192.1999.tb00175.x

Siebert, L. L. (2003). Student and teacher beliefs about language learning. The Ortesol Journal, 21, 7-39.

Suwanarak, K. (2012). English language learning beliefs, learning strategies and achievement of Masters Students in Thailand. TESOL in Context. Retrieved from http://www.tesol.org.au/files/files/275_kasma_suwanarak.pdf

Tahaineh, Y. \& Daana, H. (2013). Jordanian undergraduates' motivations and attitudes towards learning English in EFL context. International Review of Social Sciences and Humanities, 4(2), 159-180. Retrieved from http://www.irssh.com/yahoo_site_admin/assets/docs/15_IRSSH-433-V4N2.44203943.pdf

Tercanloglu, L. (2005). Pre-service EFL teachers' beliefs about foreign language learning and how they relate to gender. Electronic Journal of Research in Educational Psychology, 5-3(1), 145-162.

Truitt, S. N. (1995). Anxiety and beliefs about language learning: A study of Korean university students learning English. Doctoral Dissertation, University of Texas, Department of Curriculum and Instruction, Austin, TX.

Zhou, Z. (2018). On the Relationship of Students' English Learning Beliefs and Learning Strategy in the University. Journal of Language Teaching and Research, 1(9), 175-180. https://doi.org/10.17507/jltr.0901.22

\section{Copyrights}

Copyright for this article is retained by the author(s), with first publication rights granted to the journal.

This is an open-access article distributed under the terms and conditions of the Creative Commons Attribution license (http://creativecommons.org/licenses/by/4.0/). 